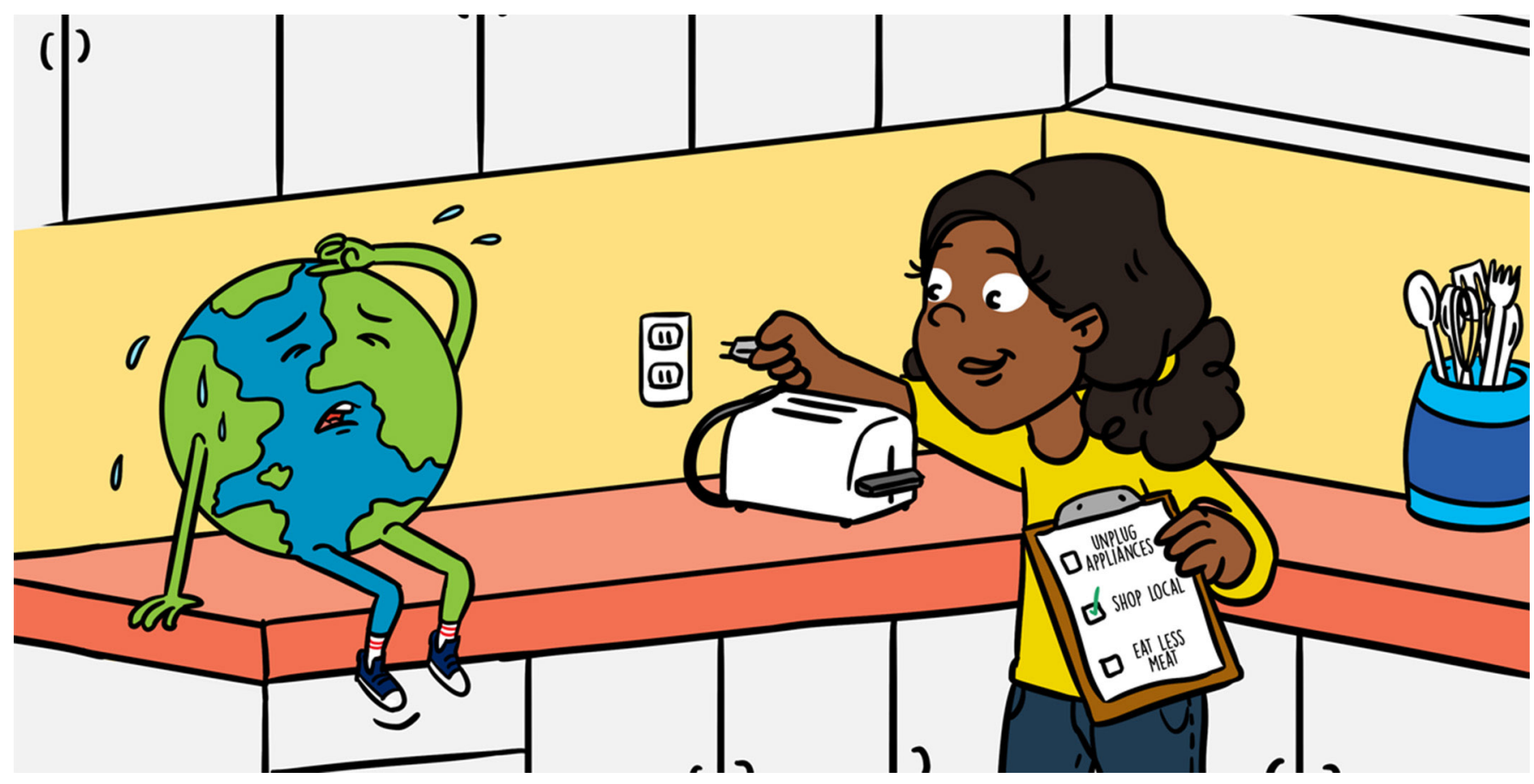

\title{
CURRENT CLIMATE CHANGE AND THE FUTURE OF LIFE ON THE PLANET
}

\section{Alex Hubbe ${ }^{1 *}$ and Mark Hubbe ${ }^{2}$}

Departamento de Oceanografia, Instituto de Geocienncias, Universidade Federal da Bahia, Salvador, Brazil

2 Department of Anthropology, The Ohio State University, Columbus, OH, United States

YOUNG REVIEWERS:

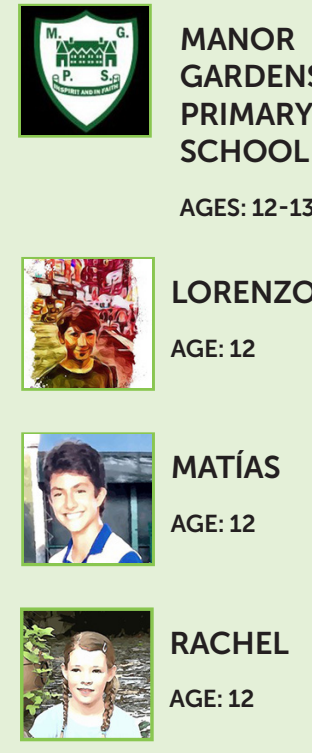

Since the Industrial Revolution, Earth's climate has been changing fast. Human actions are the major factor promoting this intense pace. In particular, the massive use of fossil fuel (oil, charcoal, gas) releases a large amount of carbon dioxide $\left(\mathrm{CO}_{2}\right)$ into the atmosphere, which concentrates, and warms the planet. So far, this climate change has not affected life on Earth too much. However, it is threatening the existence of several life forms that have to endure this climate change coupled with other human-induced changes (for example, deforestation). All these factors combined may soon affect us, too. For instance, the availability of food may be drastically reduced. In this article, we talk about the link between human activities and climate change, because humanity can still slow down its impact on the planet. There are many things everyone can do to help slow the climate change and life form extinctions in the near future. 


\section{Figure 1}

(A) The changes in average temperature and $\mathrm{CO}_{2}$ levels over the last 100,000 years.

(B) The changes in average temperature and $\mathrm{CO}_{2}$ levels between the years 1880 and 2016. In both (A, B), the blue-red line represents temperature changes and the green-brown line represents $\mathrm{CO}_{2}$ variation. From these graphs, you can clearly see that: (1) climate change and $\mathrm{CO}_{2}$ variation are closely related; (2) climate has been changing over thousands of years; and (3) Earth is warming fast since 1880.

(C) Greenhouse gases are gases capable of warming the Earth and the Atmosphere.

Release of greenhouse gases into the atmosphere (upward arrows) and removal from the atmosphere (downward arrows) are shown. Red arrows represent anthropogenic-related emissions, and green arrows represent natural emissions (Data for $A$ and $B$ come from NASA, USA, and the National Oceanic and Atmospheric Administration, USA).

\section{CLIMATE IS CHANGING VERY FAST TODAY AND THIS IS NOT NATURAL}

Do you know the difference between weather and climate? The weather is composed of a series of physical properties, like temperature, rainfall, wind speed, and many other characteristics that change according to seasons, days, or even hours. When we consider the weather over long periods of time (30 years or more) we are talking about climate. Our planet's climate is constantly changing over time (Figure 1A). Some time periods in the past were considerably warmer and others considerably colder than today and similar changes will happen in the future.
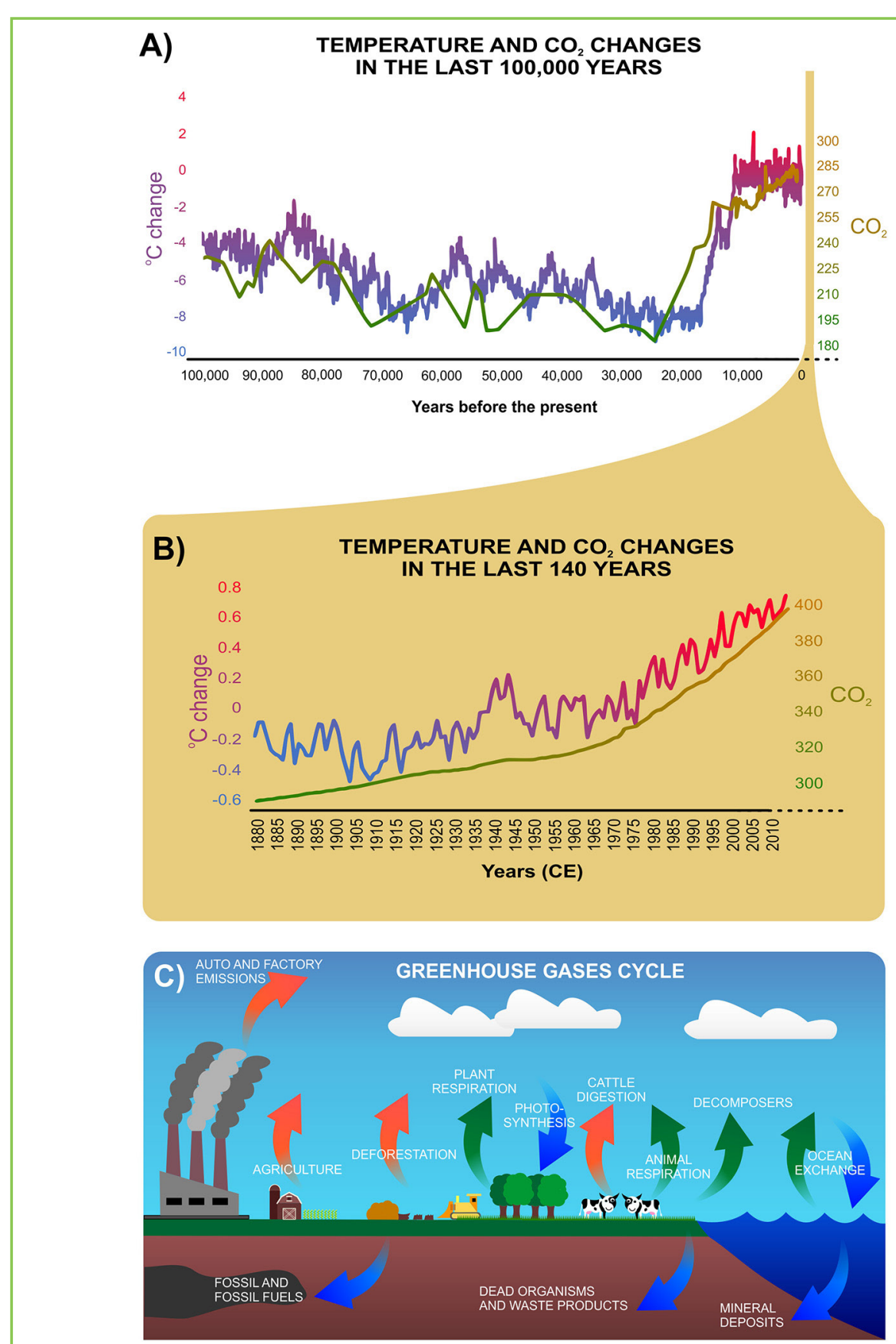

Figure 1 


\section{FOSSIL FUEL}

A source of energy formed by the transformation of the remains of dead plants and animals that were buried millions of years ago. Examples: oil, charcoal, and gas.
Around 20,000 years ago, the last cooling phase ended, starting a warming period until around 8,000 years ago, during which Earth's average temperature rose between 5.6 and $8.5^{\circ} \mathrm{F}\left(3.1-4.7^{\circ} \mathrm{C}\right)$ [1]. This means a change of around $0.06^{\circ} \mathrm{F}\left(0.03^{\circ} \mathrm{C}\right)$ every century. Between 8,000 years ago and the Industrial Revolution (around 200 years ago), temperatures were relatively constant. Since then, temperatures have been increasing again, and very quickly (Figures 1A,B). By 2100, scientists believe that the mean temperature on the planet will have raised an additional $3.6-8.8^{\circ} \mathrm{F}\left(2.0-4.9^{\circ} \mathrm{C}\right)$ compared with the temperatures at the time of the Industrial Revolution [2]. This means that the planet's temperature rise in the next century will be about 100 times faster than what happened during the last 20,000 years. While past changes in climate were the result of several factors, like the amount of energy coming from the sun and the concentration of different atmospheric gases, this time humans are mainly responsible. And that is why we call the current warming the anthropogenic (or human-induced) climate change.

Since the Industrial Revolution, our species has been burning immense amounts of fossil fuel to support our ever-growing demand for energy. Primarily through this activity, over the last 200 years, humans have increased the amount of carbon dioxide $\left(\mathrm{CO}_{2}\right)$ in the atmosphere by about $46 \%$. And $\mathrm{CO}_{2}$ is not the only factor affecting climate. The use of fossil fuels, agriculture, industrial processes, and deforestation emit other substances (or prevent them from naturally decreasing) that contribute to climate changes (Figure $1 \mathrm{C}$ ).

The anthropogenic climate change may not seem much to us now, but it will have a huge impact on humankind within the current and next few generations. The frequency and intensity of natural phenomena, like droughts and storms, will very likely increase with several consequences to humans (Table 1). Even our shorelines will dramatically change as the oceans rise, primarily due to the melting of the ice caps. This may result in the abandonment of entire coastal cities, like New York, Miami, Rio de Janeiro, Amsterdam, and Bangkok.

Climate change will also affect life forms on the planet. Several microbes, plants, and animals will probably become extinct. Just to give you a glimpse of how life can change in response to climate change, only 6,000 years ago the Sahara Desert, one of the driest places on Earth today, was covered by lush vegetation. This green landscape was a result of the more humid conditions back then [3]. 


\section{Table 1}

Major direct impacts on human lives due to the anthropogenic climate change (Information adapted from the Intergovernmental Panel on Climate Change)

\section{MIGRATION}

Movement of individuals from a species to find more favorable environments.

\section{EVOLUTION}

The changes occurring over generations of life forms. It is usually most easily seen in the observable characteristics of individuals, such as size, fur color, and behavior.

\begin{tabular}{ll}
$\begin{array}{ll}\text { Climate change will result in } \\
\text { more frequent/more intense: }\end{array}$ & And the consequences to humans might be: \\
Heat waves & Increase of death in elderly and poor \\
& $\begin{array}{l}\text { Increase in heat stress in livestock and agriculture } \\
\text { Change in tourism destinations }\end{array}$ \\
Rainfall & $\begin{array}{l}\text { Increase in floods } \\
\text { Increase in soil erosion }\end{array}$ \\
Drought & Decrease in crop and livestock production \\
& $\begin{array}{l}\text { Decrease in quantity and quality of water } \\
\text { Increase in forest fires }\end{array}$ \\
Storms & Increase property and infrastructure losses \\
& Increase in infectious disease epidemics \\
& Increased risk to human life \\
& Increase in coastal erosion \\
\hline
\end{tabular}

Table 1

\section{SO, WHAT HAPPENS TO LIVING BEINGS WHEN THE CLIMATE CHANGES?}

Climate changes affect how living beings interact with each other and with the environment they live in. When faced with climate challenges, species have two main options (which can also happen in combination). The first is to migrate. For example, as the ocean surface temperatures increase due to the anthropogenic climate change, several species, from algae to fishes, are moving toward the poles in search of colder waters [4]. For migration to happen, species must be able to find another place where they can survive and prosper. This is easier, as you can imagine, for species that are able to travel long distances during their lifetimes, like whales and cougars. However, it can be very hard for species that cannot travel long distances or that do not disperse seeds very far or very often, like sloths and orchids.

The other way a species can survive is to evolve. Evolution can happen on a small scale. For example, over a few generations, alpine chipmunks (Tamias alpinus) at Yosemite National Park, California, USA, evolved longer faces over 100 years in response to climate change [5]. Evolution can also happen on a large scale, resulting in the origin of new species. For instance, brown bears (Ursus arctos) and polar bears (Ursus maritimus) evolved from the same species of bear in a process that started around 480-340 thousand years ago, as the two groups accumulated more and more differences over time [6].

Sadly, when species cannot migrate or evolve in response to the changes in the environment, they become extinct. Human lifestyle and the rapidly increasing number of humans on the planet impose a series of challenges for the survival of several species (Figure 2). 
Figure 2

(A) Vertebrate extinction rates since the year 1500. The dotted line ("Background") represents the amount of extinction expected without human influence. You can see that the amount of extinctions caused by humans has increased over time, and is several times larger than the background extinction rate.

(B) Major ways that humans are causing extinctions (Image redrawn from Ceballos et al. [9])

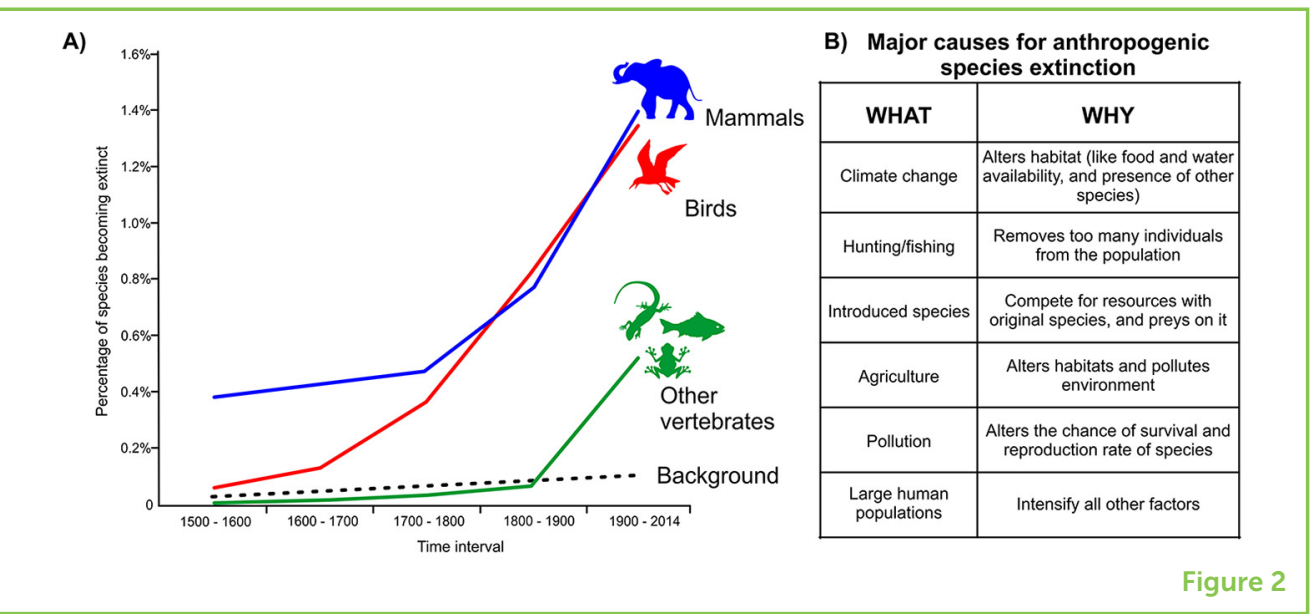

Around two vertebrate species became extinct per year during the last 100 years, mainly due to human causes [7]. Some examples of the many harmful byproducts of our lifestyle are the intense deforestation due to agriculture and the pollution of air and water. Anthropogenic climate change deserves special attention, because it is different from other human impacts. Anthropogenic climate change has a global effect, even on areas that are seldom disturbed by other human impacts, such as some protected areas. In addition, anthropogenic climate change is happening too quickly for several species to be able to migrate or evolve. This means that anthropogenic climate change is a serious threat to species that are already struggling to survive on an extensively human-transformed Earth. The take-home message here is: humans are causing a long-lasting and devastating impact on life on Earth. To put it in numbers, it is possible that over $75 \%$ of all species, three out of every four species that currently exist, will be extinct a few centuries from now [8]!

Extinction of exquisite life forms is sad in itself, but the problem of extinction goes far beyond just the disappearance of these organisms. We rely on many of them to survive. The quality of the air we breathe, the water we drink, and the food we eat, just to name a few, are directly related to the existence and the health of several other species.

In addition, we also study other lifeforms to find solutions to our own problems. For instance, the hook-and-loop fastener (a.k.a. VELCRO) was developed after studying the burrs (seeds) of a plant called burdock, which naturally attach to clothes. Several medicines have been discovered in different life forms and were only later synthesized in laboratories. There are countless inventions/discoveries waiting for us to find by studying nature, but they are only available while the species that can help us are still alive on the planet. 


\section{CARBON}

NEUTRALITY

The quantity of $\mathrm{CO}_{2}$ produced is balanced by the removal of an equal amount of $\mathrm{CO}_{2}$ from the atmosphere resulting in zero net carbon emissions

\section{BE PART OF THE SOLUTION!}

All over the world, people are working together to lessen the effects of climate change and other negative human impacts on the planet. The Paris Agreement, which started in 2016, is a good example of this. This agreement is a global effort to prevent global temperatures from rising more than $3.6^{\circ} \mathrm{F}\left(2^{\circ} \mathrm{C}\right)$ in relation to the period before the Industrial Revolution. The basic idea is to drastically reduce global emissions of $\mathrm{CO}_{2}$ and other substances that contribute to climate change. Currently, 185 countries out of almost 200 have joined in support of the Paris Agreement. The Danish city of Copenhagen has an ambitious plan, too. It wants to become a carbon-neutral city by 2025. To this end, among other things, the city is changing its energy production from fossil fuel to mainly wind-and animal/plant waste-derived energy, reducing the amount of trash produced, and transforming the city in a huge bicycle path. In several countries, scientists have been studying different ways to remove $\mathrm{CO}_{2}$ from the atmosphere and turn it into something useful. Some researchers, for example, are studying how to use bacteria to turn $\mathrm{CO}_{2}$ into fuel.

However, in a planet with over 7.6 billion people, we all need to change our ways of living to minimize anthropogenic climate change. There are many ways that each of us can do our part. A good first step is to calculate your family's carbon footprint. The carbon footprint measures how much $\mathrm{CO}_{2}$ we are emitting into the atmosphere over a certain period of time. You can calculate your carbon footprint using different calculators online. One of the many possibilities is https:// coolclimate.berkeley.edu/calculator. And once you know your carbon footprint, try to reduce it! You will be amazed by how many things we do that impact the planet. The bright side is that there are also many simple ways to reduce our negative impact. Here are some easy things any of us can do to help prevent anthropogenic climate change: http://www.un.org/sustainabledevelopment/takeaction/. A few of these easy actions include: do not buy things you do not need, unplug appliances and turn off the lights you are not using, take shorter showers, eat less meat, poultry, and fish, shop locally and from sustainable sources, and use your bike or public transportation instead of a car whenever possible. Simple actions like these can make a big difference if enough of us perform them! We should all try to reduce our carbon footprints as much as we can, because we will then reduce our impact on anthropogenic climate change and the related negative consequences for life on Earth.

Let us change the world in a cooler way! 


\section{ACKNOWLEDGMENTS}

We are deeply indebted to the awesome young reviewers Rachel, Lorenzo, Matias, and the 48 students of the Manor Gardens Primary School. We are also very thankful to mentors Luisa and David, and editors Martha and Susan. They all provided insightful comments on a previous draft of this manuscript.

\section{REFERENCES}

1. Annan, J. D., and Hargreaves, J. C. 2013. A new global reconstruction of temperature changes at the last glacial maximum. Clim. Past 9:367-76. doi: $10.5194 / c p-9-367-2013$

2. Raftery, A. E., Zimmer, A., Frierson, D. M. W., Startz, R., and Liu, P. 2017. Less than $2^{\circ} \mathrm{C}$ warming by 2100 unlikely. Nat. Clim. Change 7:637-41. doi: $10.1038 /$ nclimate3352

3. deMenocal, P., Ortiz, J., Guilderson, T., Adkins, J., Sarnthein, M., Baker, L., et al. 2000. Abrupt onset and termination of the African humid period: rapid climate responses to gradual insolation forcing. Q. Sci. Rev. 19:347-61. doi: 10.1016/ S0277-3791(99)00081-5

4. Poloczanska, E. S., Brown, C. J., Sydeman, W. J., Kiessling, W., Schoeman, D. S., Moore, P. J., et al. 2013. Global imprint of climate change on marine life. Nat. Clim. Change 3:919-25. doi: 10.1038/nclimate1958

5. Walsh, R. E., Assis, A. P. A., Patton, J. L, Marroig, G., dawson, T. E., and Lacey, E. A. 2016. Morphological and dietary responses of chipmunks to a century of climate change. Glob. Change Biol. 22:3233-52. doi: 10.1111/gcb.13216

6. Liu, S., Lorenzen, E. D., Fumagalli, M., Li, B., Harris, K., Xiong, Z., et al. 2014. Population genomics reveal recent speciation and rapid evolutionary adaptation in polar bears. Cell 157:785-94. doi: 10.1016/j.cell.2014.03.054

7. Ceballos, G., Ehrlich, P. R., and Dirzo, R. 2017. Biological annihilation via the ongoing sixth mass extinction signaled by vertebrate population losses and declines. Proc. Natl. Acad. Sci. U.S.A. 114:E6089-96. doi: 10.1073/pnas.1704949114

8. Barnosky, A. D., Matzke, N., Tomiya, S., Wogan, G. O. U., Swartz, B., Quental, T. B., et al. 2011. Has the earth's sixth mass extinction already arrived? Nature 471:51-7. doi: 10.1038/nature09678

9. Ceballos, G., Ehrlich, P. R., Barnosky, A. D., Garcia, A., Pringle, R. M., and Palmer, T. M. 2015. Accelerated modern human-induced species losses: entering the sixth mass extinction. Sci. Adv. 1:e1400253. doi: 10.1126/sciadv.1400253

SUBMITTED: 31 March 2018; ACCEPTED: 18 February 2019;

PUBLISHED ONLINE: 07 March 2019.

EDITED BY: Martha Helena Ramírez-Bahena, Spanish National Research Council (CSIC), Spain 

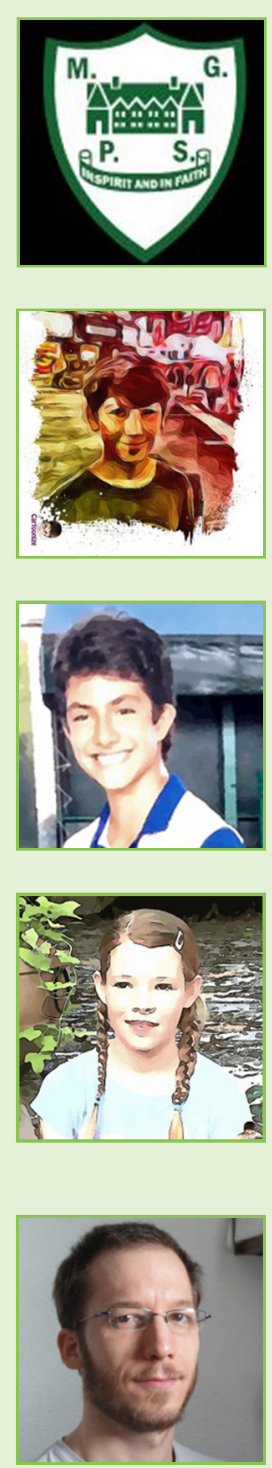

CITATION: Hubbe A and Hubbe M (2019) Current Climate Change and the Future of Life on the Planet. Front. Young Minds 7:37. doi: 10.3389/frym.2019.00037

CONFLICT OF INTEREST STATEMENT: The authors declare that the research was conducted in the absence of any commercial or financial relationships that could be construed as a potential conflict of interest.

COPYRIGHT () 2019 Hubbe and Hubbe. This is an open-access article distributed under the terms of the Creative Commons Attribution License (CC BY). The use, distribution or reproduction in other forums is permitted, provided the original author(s) and the copyright owner(s) are credited and that the original publication in this journal is cited, in accordance with accepted academic practice. No use, distribution or reproduction is permitted which does not comply with these terms.

\section{YOUNG REVIEWERS}

\section{MANOR GARDENS PRIMARY SCHOOL, AGES: $12-13$}

We are a small, progressive, problem-solving school that encourages independent thinking. We challenge ourselves and our teachers and have lots of fun during the school day.

\section{LORENZO, AGE: 12}

$\mathrm{Hi}$, I am 12 years old and I love football and video games. My five pets: three dogs and two cats are an important part of my life.

\section{MATÍAS, AGE: 12}

I am a 12 years old boy who loves science, programming, Vikings, mythology, JiuJitsu, rock and roll, and playing drums.

\section{RACHEL, AGE: 12}

I am a 12 years old girl and I like to play tennis and ice hockey. I like horses and all animals.

\section{AUTHORS}

\section{ALEX HUBBE}

I am an Associate Professor at the Instituto de Geociências, Universidade Federal da Bahia, Brazil. I am a paleontologist and an evolutionary biologist, particularly interested in studying the extinction and evolution of mammals. Since my daughter Lara was born, I am also very interested in finding ways by which I can help create a more sustainable world. In my free time, I like to be with Lara and my wife Olívia, ride my bicycle, and swim. *alexhubbeayahoo.com 


\section{MARK HUBBE}

I am an Associate Professor at the Department of Anthropology of the Ohio State University, USA. My research area is the settlement of the Americas and the study of prehistoric human populations from South America. I believe that the study of our past informs us about who we are and shows us that we must understand how we interact and change our environment, so that we can create a sustainable future. In my spare time, I love to climb, hike, and enjoy nature. 